\title{
LC-MS Phytochemical Screening, In Vitro Antioxidant, Antimicrobial and Anticancer Activity of Microalgae Nannochloropsis oculata Extract
}

\author{
Adil Farooq Wali ${ }^{1, *}$, Yusra Al Dhaheri ${ }^{2}$, Jayachithra Ramakrishna Pillai ${ }^{1}$, Ahlam Mushtaq ${ }^{3}$, \\ Padma G. M. Rao ${ }^{4}$, Syed Arman Rabbani ${ }^{4}$, Aimen Firdous ${ }^{5}$, Mohamed Soliman Elshikh ${ }^{6}$ \\ and Dunia A. Al Farraj ${ }^{6}$ \\ 1 Department of Pharmaceutical Chemistry, RAK College of Pharmaceutical Sciences, RAK Medical and \\ Health Sciences University, Ras Al Khaimah 11172, UAE; jayachithra@rakmhsu.ac.ae \\ 2 Department of Biology, College of Science, United Arab Emirates University, Al Ain 15551, UAE; \\ yusra.aldhaheri@uaeu.ac.ae \\ 3 Department of Biochemistry, Government Medical College (GMC), Karan Nagar, Srinagar 190010, India; \\ dr.ahlammushtaq@gmail.com \\ 4 Department of Clinical Pharmacy and Pharmacology, RAK College of Pharmaceutical Sciences, RAK \\ Medical and Health Sciences University, Ras Al Khaimah 11172, UAE; padma@rakmhsu.ac.ae (P.G.M.R.); \\ arman@rakmhsu.ac.ae (S.A.R.) \\ 5 Department of Processing Technology, Kerala University of Fisheries and Ocean Studies (KUFOS), \\ Panangad, Kerala 682506, India; czarfirdous@gmail.com \\ 6 Department of Botany and Microbiology, College of Science, King Saud University, \\ Riyadh 11451, Saudi Arabia; melshikh@ksu.edu.sa (M.S.E.); dfarraj@ksu.edu.sa (D.A.A.F.) \\ * Correspondence: farooq@rakmhsu.ac.ae
}

Received: 24 August 2020; Accepted: 18 September 2020; Published: 8 October 2020

\begin{abstract}
Nowadays, marine microalgae are recognized to be a considerably novel and rich origin of bioactive moieties utilized in the sectors of nutraceuticals and pharmaceuticals. In the present study, Nannochloropsis oculata extract (AME) was associated with a wide variety of pharmacological studies such as in vitro antioxidant, antibacterial, and antifungal and anticancer activity (MDA-MB-231) in cancer cells through in vitro models. In the study, the chemical composition and structure of the bioactive compounds found in the AME extract were studied using the LC-MS technique. The results of the anticancer activity showed a decrease in the percentage of cell viability of the MDA-MB-231 cells in a concentration- and time-dependent manner $(400 \mu \mathrm{g} / \mathrm{mL}$ at $24 \mathrm{~h}, 300 \mu \mathrm{g} / \mathrm{mL}$ at $48 \mathrm{~h}$, and $200 \mu \mathrm{g} / \mathrm{mL}$ at $72 \mathrm{~h}$ ). We have also observed morphological changes in the cells that could be associated with treatment with AME extract. Our observation of the AME extract-treated MDA-MB231 cells under light microscopy showed that when the concentration increased, the number of cells began to decrease. As far as LC-MS analysis is concerned, it showed the presence of the bioactive molecules was terpenoids along with carotenoids, polyphenolic and fatty acids. The result revealed that the AME extract exhibited noteworthy in vitro free radical scavenging potential, with an $\mathrm{IC}_{50}$ value of $52.10 \pm 0.85 \mu \mathrm{g} / \mathrm{L}$ in DPPH assay, $122.84 \pm 2.32 \mu \mathrm{g} / \mathrm{mL}$ in $\mathrm{H}_{2} \mathrm{O}_{2}$ assay and, $96.95 \pm 1.68 \mu \mathrm{g} / \mathrm{mL}$ in ABTS assay. The activity was found to be highly significant against bacteria (Gram-positive and negative) and moderately significant against fungal strain with minimum inhibitory concentration (MIC) and minimum bactericidal concentration (MBC)/minimum fungicidal concentration (MFC) values between 15.63 and $500 \mu \mathrm{g} / \mathrm{mL}$.
\end{abstract}

Keywords: Nannochloropsis oculata; MDA-MB-231 cells; antioxidants assay; polyphenols; antimicrobial 


\section{Introduction}

Natural products are important components of medicines. The use of plants as medicine may date back to the ancient period. Nature has created a rich repository of herbal medicine to treat human disease [1]. The discovery of therapeutic potential in flora and fauna has driven the disclosure of bioactive compounds, with significant implications in the laboratory context, and recognition of dynamic concepts of clinical value [2]. Marine natural products were, moreover, the target of finding novel drugs of chemical and biological significance. Marine organisms are the source of major new drugs with numerous different biological activities [3]. Microalgae could be found over almost all ecosystems and habitats on the planet, from the Northern Hemisphere to the equator. They may be free-floating or growing attached to substrates. Microalgae may even form mattresses on silt surfaces [4]. There is a possibility of the well-founded opportunity for a larger range of microalgae species to be utilized for human nourishment. A wide variety of microphytes comprise very rich sources proteins for humans [5]. A few of the most widely accepted microalgae pigments are essential for human health, have anticancer properties, and function as antioxidants. Nutritious polyunsaturated fatty acids prosper in a few algal species, advertising imperative fatty acids required for human wellbeing. Despite these prospects, few microalgae species have been identified for use during the nutritional sciences industry [6]. Microalgae manufacture a variety of secondary metabolites with biological effects, including anticancer, antimicrobial, antifungal, antiviral, anti-inflammatory, and other substances, and are a possible future source of novel therapeutic drugs [7]. They produce various bioactive molecules as a reaction to ecological pressure. They are essential biological resources that have a large number of physical, biological, and molecular approaches to handle stress. They have a broad range of metabolites and natural active components such as fatty acids, polysaccharides, phycocyanins, carotenoids, terpenoids, enzymes, and phenolic compounds [8]. The analysis of macro-algae extracts has recently been studied for their significant effectiveness in the prevention of different diseases. Despite the enormous proportion of marine algae in this region, only a few studies have been performed regarding the phytochemical, antioxidant, and pharmacological activities of algae $[9,10]$.

Cancer has become one of the world's leading adverse health effects with significant social and economic implications. Presently, cancer incidence rates account for one in seven deaths in the world, with far more deaths than AIDS, tuberculosis, and malaria combined [11]. A major number of women across the world die of breast cancer [12]. Of all breast cancers, a subtype of cancer that lacks three receptors (progesterone, estrogen, and HER2) known as triple-negative breast cancer (TNBC) constitutes about $15 \%$ in the United States of America. TNBC is distinguished by its attacking nature, unique molecular structure, lack of active treatment, and specific metastatic trends [13]. The essentiality of the presence of receptors for cancer cells makes common medications such as hormone therapy and estrogen, progesterone, and HER-2 targeting drugs ineffective. Therefore, chemotherapy using the cytotoxic drug that inhibits cancer cells is mainly used in the treatment of TNBCs. TNBCs often exhibit metastasis to secondary sites such as the brain and lungs. Furthermore, they are extremely proliferative and consistently develop resistance against chemotherapeutic agents [14]. Natural compounds are an extremely valuable resource of biologically active moieties which play a major role in the quest for new drugs by acting as lead molecules for the discovery of new drug candidates [15]. Natural compounds, obtained from various sources, act as a reserve of biologically active compounds that have transformed and improved the range of cancer treatment [16]. At present, the percentage of drugs derived from natural sources, with anticancer potential, is quite high corresponding to approximately 60 percent [17]. Several research findings have reported microalgae species with anti-cancer properties [18].

The green algae genus Nannochloropsis (Order: Eustigmatales; Family: Eustigmatophyceae.) is characterized by unicellular lacking flagella, planktonic, with 3 to $4 \times 1.5 \mu \mathrm{m}$ cylindrical cells [19]. They seem to be mostly rich in phytochemicals, making them suitable to be utilized as a nutritive supplement and natural therapy for the management of several ailments due to their ability to accumulate elevated levels of PUFAs (polyunsaturated fatty acids) [20]. 
This research was aimed at performing the phytochemical screening and assessing the antioxidant, antimicrobial, and anticancer activity of Nannochloropsis oculata.

\section{Material and Methods}

\subsection{Preparation of Material and Extraction}

Nannochloropsis oculata was cultured in the laboratory by adapting Sharifah et al. [21] culture technique. An amount of $100 \mathrm{~g}$ of microalgae (Nannochloropsis oculata) was thoroughly washed with demineralized water. The algae are therefore transferred to an Erlenmeyer flask and extracted with absolute methanol using an ultrasonic homogenizer (BioLogics, Inc., Manassas, VA, USA) for $1 \mathrm{hr}$ at RT, $15 \mathrm{kHz}$. The mixture was filtered and using a rotary evaporator (Buchi Rotavapor ${ }^{\circledR} \mathrm{R}-210$, Flawil, Switzerland) the solvent was removed. By making use of freeze-drying technique the mass was lyophilized. The Nannochloropsis oculata extract (AME) was then placed in a desiccator to store it for further evaluation.

\subsection{Total Phenolics Content (TPC)}

Folin-Ciocalteu test was employed to estimate the TPC of AME extract following the methodology of Aryal et al. [22]. The standard reference sample used for plotting curve was gallic acid $(20-100 \mu \mathrm{g} / \mathrm{mL})$ and the TPC of AME extract was reported w.r.t gallic acid as $\mu \mathrm{g} / \mathrm{mg}$ of corresponding gallic acid i.e., $\mathrm{GAE} / \mathrm{mg}$.

\subsection{Total Flavonoid Content (TFC)}

To evaluate this parameter the technique of colorimetry was employed as reported by Shi et al. [23]. For plotting the curve, the reference standard used was quercetin $(20-100 \mu \mathrm{g} / \mathrm{mL})$. AME extract was reported as $\mu \mathrm{g} / \mathrm{mg}$ of the corresponding quercetin i.e., $\mathrm{QE} / \mathrm{mg}$.

\subsection{Tannins Content (TC)}

The methodology outlined by Siddhuraju et al. [24] was employed to measure the tannins content of the AME extract.

\subsection{In Vitro Antioxidant Activity}

The free radical scavenging potential of AME extract was assessed by DPPH assay [25], $\mathrm{H}_{2} \mathrm{O}_{2}$ assay [26] and ABTS assay [27]. The AME extract was compared to the reference standard butylated hydroxyanisole (BHA) and was evaluated in triplicate.

The value of $\mathrm{IC}_{50}$ defines the extract concentration that inhibits $50 \%$ of the radicals. The anti-radical concentration for $50 \%$ of $\mathrm{DPPH}, \mathrm{H}_{2} \mathrm{O}_{2}$ and $\mathrm{ABTS}$ free radical was quantified from the logarithmic regression equation.

\subsection{Phytochemical Screening of AME Extract by Using LC-MS}

The chemical screening of AME extract was performed on an LC-MS instrument connected to HPLC with an ESI interface. For chromatographic separation Acquity C18 column $(100 \times 4.6) \times 5 \mu \mathrm{m}$ was used. Isocratic elution condition was employed for mobile phase with A:B Methanol:2mM Ammonium acetate:formic acid (65:35:0.1) maintaining a flow rate of $0.6 \mathrm{~mL} / \mathrm{min}$. The linearity was achieved from 1 to $250 \mathrm{ppm}$. The LC-MS conditions were voltage $30 \mathrm{~V}$, capillary voltage $3.5 \mathrm{~V}$, desolvation gas $900 \mathrm{~L} / \mathrm{h}$, desolvation temperature $400{ }^{\circ} \mathrm{C}$, cone gas $50 \mathrm{~L} / \mathrm{h}$, source temp $150{ }^{\circ} \mathrm{C}$, collision energy $22 \mathrm{~V}$. The ionization was carried out in positive ion mode. The spectral data were obtained using PDA detector. To verify the compounds, all the data, procurements, and evaluations were regulated using the database library. 


\subsection{In Vitro Cytotoxicity Assay}

\subsubsection{Cell Line and Cell Culture}

The cell line utilized for this study was triple-negative human breast cancer cell line (MDA-MB-231). The cell lines were provided with Dulbecco's Modified Eagle's Medium (DMEM). The medium of culture that included Dulbecco phosphate-buffered saline (DPBS) was accompanied by bovine fetal serum $(10 \%)$ along with streptomycin/penicillin $(100 \mathrm{U} / \mathrm{mL})$ at $37{ }^{\circ} \mathrm{C} 5 \%, 95 \%$ humidity and $\mathrm{CO}_{2}$. After the removal of confluent media, the washing of sub-cultured cells was done with phosphate saline buffer (1×), then Trypsin was added to MDA-MB-231 cells for detaching the cells from substrate surface and counting the cells (cells/mL) at the time of plates seeding for cell viability experiment

\subsubsection{Treatment of AME Extract to MDA-MB-231}

MDA-MB-231 cells were transferred into 96-well plates. The density at which seeding was performed was 5000 cells/well. This was followed by overnight incubation of seeded plates which were then tested with increasing concentrations of AME extract, dissolved in 70\% ethanol (50, 100, 200, 400 and $600 \mu \mathrm{g} / \mathrm{mL}$ ) or ethanol (control). These were then incubated for another 24, 48 and $72 \mathrm{~h}$. Cells were then subjected to cell viability measurement.

\subsubsection{Measurement of Cell Viability}

The cell viability measurement, at the indicated times was done by removing the media from each well then $50 \mu \mathrm{L}$ of fresh media was added first, followed by addition of CellTiter-Glo (Promega, Madison, WI, USA) reagent $(50 \mu \mathrm{L})$. After mixing the plate for $2 \mathrm{~min}$, another $10 \mathrm{~min}$ incubation period was done at room temperature. After that, luminescence was noted using the GloMax ${ }^{\circledR}$ Explorer Multimode Detection System. CellTiter-Glo measures the amount of ATP signaling the prevalence of metabolically active cells. Data was provided as proportional viability (\%) by equating the data for treated cells to untreated cells (possessing the viability of 100 percent).

\subsection{Antimicrobial Activity}

To assess the antimicrobial activity, the agar well plate technique for determination of minimum inhibitory concentration (MIC), minimum bactericidal concentration (MBC), and minimum fungicidal concentration (MFC) values was used [28]. Four different American Type Culture Collection (ATCC) strain/s of microbes (bacteria and fungi) were used for the study, they are: Staphylococcus aureus ATCC 25923 (Gram-positive bacteria), Pseudomonas aeruginosa ATCC 27853, Escherichia coli ATCC 25922 (Gram-negative bacteria) and Candida albicans ATCC 24433 (Yeast). Three replicates were made against each of the tested microorganisms. The data have been presented as mean \pm standard deviation.

\subsection{Statistical Analysis}

All findings are tabulated as Mean \pm S.D. For paired or unpaired values, the Student $t$-test was performed. The $p$-value of $<0.05$ taken as significant.

\section{Results}

\subsection{Estimation of TPC, TFC, and TC}

The TPC, TFC, and TC of AME extract were measured for the assessment of chemical composition are presented in Table 1 . The AME extract was recorded as having $437 \pm 0.95 \mu \mathrm{g} Q E / g: R^{2}=0.964$ amount of flavonoid content, $53.92 \pm 0.83 \mathrm{mg} \mathrm{GAE} / \mathrm{g}$ with $\mathrm{R}^{2}=0.989$ amount of phenolic content, and $47.05 \pm 0.43 \mathrm{mg} \mathrm{GAE} / \mathrm{g}$ with $\mathrm{R}^{2}=0.955$ amount of tannins content, respectively. 
Table 1. Total phenolics content, total flavonoid content and tannins content of AME extract.

\begin{tabular}{ccccccc}
\hline Extract & $\begin{array}{c}\text { Total Phenolics } \\
\boldsymbol{\mu g ~ Q E} / \mathbf{g}\end{array}$ & $\mathbf{R}^{2}$ & $\begin{array}{c}\text { Total Flavonoid } \\
\text { mg GAE/g }\end{array}$ & $\mathbf{R}^{2}$ & $\begin{array}{c}\text { Tannins } \\
\text { mg GAE/g }\end{array}$ & $\mathbf{R}^{\mathbf{2}}$ \\
\hline AME & $437 \pm 0.95$ & 0.964 & $53.92 \pm 0.83$ & 0.989 & $47.05 \pm 0.43$ & 0.955 \\
\hline \multicolumn{7}{c}{ Tests were performed in triplicates and represented as mean \pm SD. }
\end{tabular}

\subsection{In Vitro Antioxidant Activity}

Table 2 represents the antioxidant potential of AME extract. Although the antioxidant ability of the AME extract is low with $\mathrm{IC}_{50}$ values for DPPH $52.10 \pm 0.85 \mu \mathrm{g} / \mathrm{mL}, \mathrm{H}_{2} \mathrm{O}_{2} 122.84 \pm 2.32 \mu \mathrm{g} / \mathrm{mL}$ and ABTS $96.95 \pm 1.23 \mu \mathrm{g} / \mathrm{mL}$ at $250 \mu \mathrm{g} / \mathrm{mL}$, respectively, in comparison to BHA. Activity with higher $\mathrm{IC}_{50}$ values represents less anti-oxidant activity.

Table 2. In vitro antioxidant activity of AME extract.

\begin{tabular}{|c|c|c|c|}
\hline & $\begin{array}{c}\text { DPPH } \\
\mathrm{IC}_{50} \mu \mathrm{g} / \mathrm{mL}\end{array}$ & $\begin{array}{c}\mathrm{H}_{2} \mathrm{O}_{2} \\
\mathrm{IC}_{50} \mu \mathrm{g} / \mathrm{mL}\end{array}$ & $\begin{array}{c}\text { GAE/g ABTS } \\
\text { IC }_{50} \mu \mathrm{g} / \mathrm{mL}\end{array}$ \\
\hline AME & $52.10 \pm 0.85$ & $122.84 \pm 2.32$ & $96.95 \pm 1.68$ \\
\hline BHA & $35.91 \pm 0.38$ & $64.37 \pm 1.76$ & $45.27 \pm 1.53$ \\
\hline
\end{tabular}

\subsection{Phytochemical Profiling of AME Extract by LC-MS}

A total of five bioactive molecules were identified and characterized by a correlation of the molecular (precursor) ions and the fragmentation patterns (i.e., product ions) acquired employing LC-MS analysis (Table 3). The LC-MS data were then compared to the reported literature, database, and computer repositories for reference compounds. The bioactive molecules identified in AME extract were terpenoid along with carotenoids, polyphenolic, and fatty acid compounds as shown in Figure 1. The compounds found in the AME extract were known for their pharmacological properties.

Table 3. The major components found in the AME extract based on LC-MS analysis.

\begin{tabular}{|c|c|c|c|c|c|c|}
\hline Peak No. & Compound Name & $\begin{array}{l}\text { Retention Time } \\
\text { (min) }\end{array}$ & $\begin{array}{l}\text { Molecular Formula } \\
\quad\left(\mathrm{gmol}^{-1}\right)\end{array}$ & $\begin{array}{l}\text { Theoretical } \\
(m / z)\end{array}$ & $\begin{array}{l}\text { Measured } \\
\qquad(m / z)\end{array}$ & $\begin{array}{c}\text { Percentage } \\
\text { Content }\end{array}$ \\
\hline 1. & Stigmasterol & 11.49 & $\mathrm{C}_{29} \mathrm{H}_{48} \mathrm{O}$ & 412.69 & 413.35 & 2.76 \\
\hline 2. & Unidentified & 10.50 & - & - & 609.39 & - \\
\hline 3. & Lanosterol & 9.43 & $\mathrm{C}_{30} \mathrm{H}_{50} \mathrm{O}$ & 425.30 & 426.71 & 3.98 \\
\hline 4. & Morin & 8.85 & $\mathrm{C}_{15} \mathrm{H}_{10} \mathrm{O}_{7}$ & 301.29 & 302.23 & 1.84 \\
\hline 5. & Cholesta-3,5-dien-7-one & 8.27 & $\mathrm{C}_{27} \mathrm{H}_{42} \mathrm{O}$ & 382.62 & 383.23 & 2.42 \\
\hline 6. & Unidentified & 6.75 & - & - & 290.33 & - \\
\hline 7. & Beta-carotene 5,6-epoxide & 3.41 & $\mathrm{C}_{40} \mathrm{H}_{56} \mathrm{O}$ & 552.90 & 454.34 & 8.76 \\
\hline 8. & Unidentified & 3.07 & - & - & 249.21 & - \\
\hline
\end{tabular}

\subsection{Anticancer Activity}

This part of the study was intended to measure the potential anticancer activity of AME extract. For this, the AME extract was tested in vitro for the inhibition of proliferation of neoplastic cells using human breast cancer cell line. Experimentally, an estimation of time and concentration dependence of the activity of AME was assessed. This was achieved by the incubation of MDA-MB-231 cells to a series of different concentrations of AME (50-600 $\mu \mathrm{g} / \mathrm{mL})$ performed for different time periods $(24,48$, and $72 \mathrm{~h}$ ). Our findings demonstrate that AME extract inhibited the viability of the MDA-MB231 cells in a concentration and time-dependent manner (Figure 2A). 


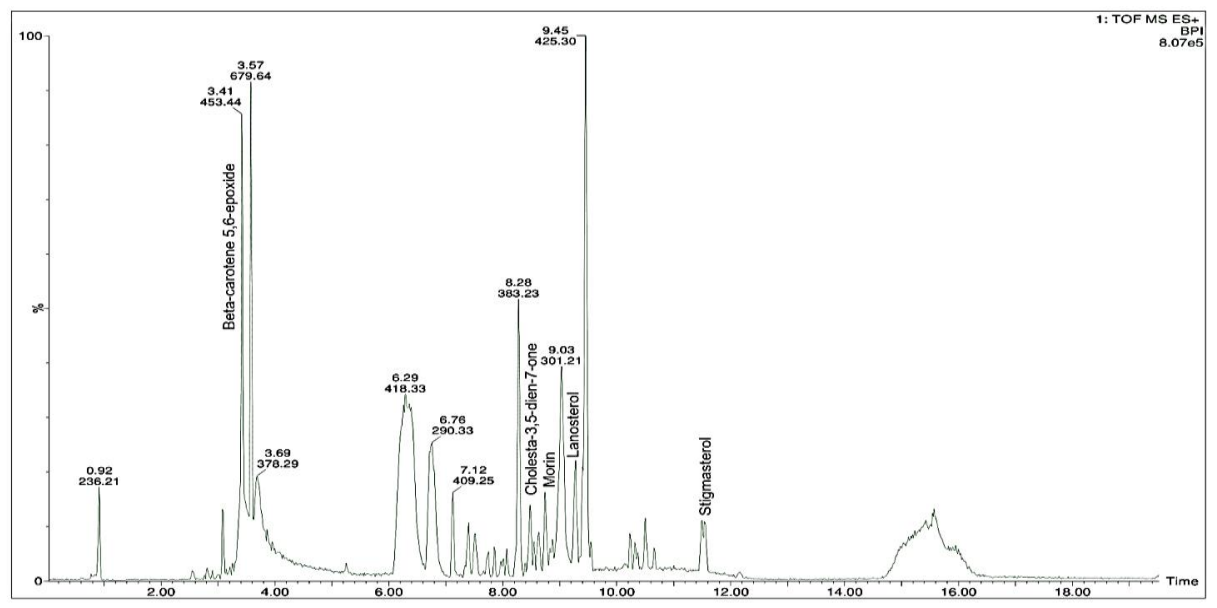

Figure 1. LC-MS chromatographic representation of AME extract in positive mode.

A.

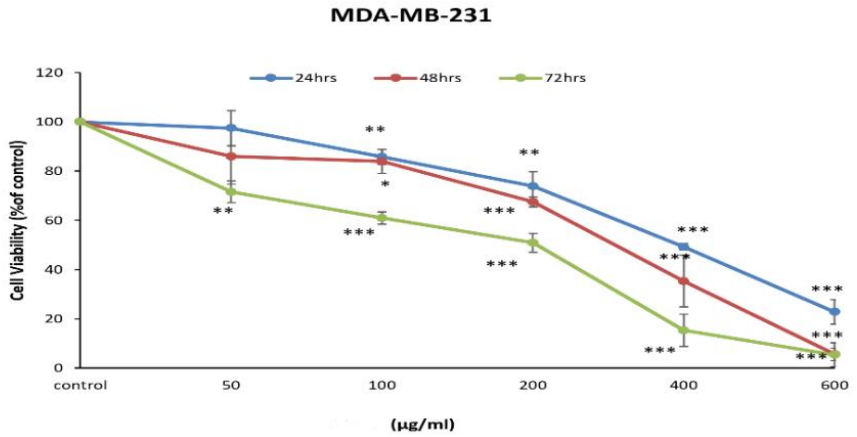

B.
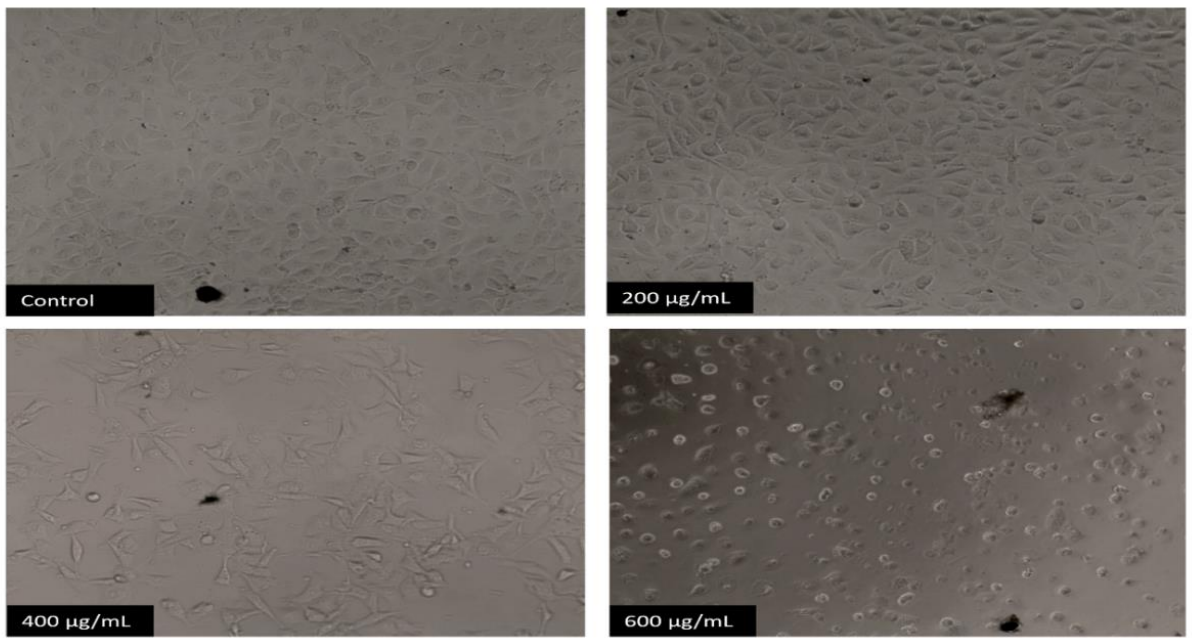

Figure 2. Impact of AME extract on morphological changes and viability of human breast cancer cells MDA-MB-231. (A) Cell viability in percentage subsequent to incubation of exponentially proliferating cells with specified concentration level of AME extract and control for 24, 48 and $72 \mathrm{~h}$. (B) After $48 \mathrm{~h}$ of incubation, the photomicrograph shows the effect of different concentrations of AME extract on MDA-MB-231 cells. The data display the mean of the test as measured in triplicate. ${ }^{*} p=0.05$, ** $p=0.005$ and $\left.{ }^{* * *} p=0.0005\right)$. 
We also monitored cell morphological changes that might be associated with AME extract treatment. The study reflected that the MDA-MB231 cells, when observed under light microscope, show a decrease in the cell count with increase in concentration of AME (Figure 2B).

\subsection{Antimicrobial Activity}

The antimicrobial potential of the AME extract was studied using Muller Hinton agar as a medium against different pathogen strains. In this investigation, for determining the antimicrobial activity of the AME extract, a sequential dilution technique was employed. Findings showed that the AME extract exhibited poor inhibitory activity on the fungi evaluated, the MIC and MFC of AME extract values against Candida albicans was higher than $500 \mu \mathrm{g} / \mathrm{mL}$. The MIC and MBC for Staphylococcus aureus was 15.62 and $31.25 \mu \mathrm{g} / \mathrm{mL}$, likewise, for Escherichia coli the MIC values were recorded to be 125 and $250 \mu \mathrm{g} / \mathrm{mL}$ and for Pseudomonas aeruginosa 62.50 and $125.00 \mu \mathrm{g} / \mathrm{mL}$ respectively as shown in Table 4 .

Table 4. Antimicrobial activity of Nannochloropsis oculata extract.

\begin{tabular}{cccc}
\hline Pathogens Strains & ZoI & MIC & $\begin{array}{c}\text { MBC/MFC } \\
\boldsymbol{\mu g} / \mathbf{m L}\end{array}$ \\
\hline Staphylococcus aureus & $10 \pm 1.23$ & 15.62 & 31.25 \\
\hline Escherichia coli & $7 \pm 1.58$ & 125 & 250 \\
\hline Pseudomonas aeruginosa & $9 \pm 1.96$ & 62.50 & 125 \\
\hline Candida albicans & $5 \pm 0.82$ & 500 & -
\end{tabular}

ZoI, zone of inhibition (mm); [-], no activity; MIC, minimum inhibition concentration ( $\mathrm{mg} / \mathrm{mL}) ; \mathrm{MBC}$, minimum bactericidal concentration $(\mu \mathrm{g} / \mathrm{mL})$; MFC, minimum fungicidal concentration $(\mu \mathrm{g} / \mathrm{mL})$.

\section{Discussion}

Microalgae exhibit a wide range of molecules that promote their sustainability and metabolism in an excessively harsh and challenging environment [29]. Research and development of new and unique bioactive components responsible for the production of their synthesis pathway of secondary metabolites have produced a resurgence of interest in the pharmaceutical industry.

Our research is among the few to simultaneously evaluate microalgae extraction, phytochemical screening, and biological activity evaluation such as anti-cancer, antioxidant, and antimicrobial activity.

Polyphenolic compounds are abundant in plants and algae, which could facilitate public health and safety [30]. Polyphenols (e.g., flavonoids) have recently been recognized to be non-toxic antioxidants [31]. Many more findings suggest that adequate nutritional quality of organic phenolics is significantly related to increased life span, substantially reduced chances of acquiring certain chronic illnesses, such as chemopreventive agents [32]. Our observation corresponds to the observation of Haoujar et al., according to whom Nannochloropsis oculata has higher polyphenol content [33] but is lower than reported by Maadane et al. [34]. Polyphenolic constituents found in the microalgae are associated with antioxidant activity and therefore are highly reliant mostly on solvent and algae organisms used during extraction [35].

The significant relationship between polyphenolic constituents and the antioxidant activity of algae is thoroughly reported [36] and as per several studies performed on microalgae, it has been found that phenolics are amongst the antioxidants of chief importance [37]. In the present study, DPPH, $\mathrm{H}_{2} \mathrm{O}_{2}$, and ABTS assays were employed for the evaluation of the antioxidant capacity of AME extract. Typically, the $\mathrm{DPPH}^{\bullet-}$ scavenging model was used to determine the potential of hydrogen to transfer atoms since the transition of hydrogen atoms is a required mechanism in the $\mathrm{DPPH}^{\bullet-}$ scavenging system [38]. DPPH is a free radical having an absorption peak at $517 \mathrm{~nm}$. The purple color of DPPH disappears easily whenever it confronts a proton radical scavenger. ABTS assay is perhaps the best technique for the evaluation of free radical scavenging ability of diverse bioactive molecules/extracts/fractions. The phenolic antioxidant compounds appear to give an electron to ABTS ${ }^{\bullet+}$ 
free radical which incapacitates the positive electrical charge present on it and as a result, a stable neutral ABTS molecule is formed [39]. Hydrogen peroxide individually is not all that reactive, although it has a deleterious effect on cells since it leads to the formation of hydroxyl radicals. Therefore, the elimination of both $\mathrm{H}_{2} \mathrm{O}_{2}$ and $\mathrm{O}_{2}{ }^{-}$is extremely essential for the protection of antioxidants in cells or nutrition [40].

The results from this study are similar to the findings of the former studies by Millao et al. [41] and Custodio et al. [42] that reported maximum scavenging activity in methanol extract attributed to polyphenols, carotenoids, polyunsaturated fatty acids, etc. [43].

The findings of the study exhibited that the AME extract successfully prohibited the proliferation of both Gram-positive as well as Gram-negative bacteria in comparison to fungi. Our observations correspond with the findings of Kokou et al. [44]. Secondary metabolites such as terpenoids [45], fatty acids [46] and, polyphenolic [47] can damage the plasma membrane of both types of bacteria. Nannochloropsis oculata will serve as a possible future source of novel phytochemical constituents of importance for diagnostic and therapeutic applications [48]. The presence of different antimicrobial compounds in extraction liquid extracts from the organisms studied might just be the cause of the increase in antimicrobial efficacy.

Cancer can be regarded as a multifactorial disease characterized by the unrestrained production and growth of cells in the body [42,49]. Microalgae are rich reservoirs of a variety of biomolecules such as pigments, fats, and fatty acids, carbohydrates, vitamins, and so on [49]. Though microalgae possess a huge array of promising biomolecules, and a variety of compounds are recovered from them with the attribution of many pharmacological activities to them, only a few recent studies have reported the anticancer activity of microalgae [50].

Our findings on MDA-MB-231 cells showed that AME extract exhibits a significant effect on their proliferation which was affected by concentration as well as time. At a concentration of about $200 \mu \mathrm{g} / \mathrm{mL}$, approximately $25 \%$ of cell-viability inhibition was reached after $24 \mathrm{~h}$. After $48 \mathrm{~h}$, more than $50 \%$ of cell-viability inhibition was reached at $400 \mu \mathrm{g} / \mathrm{mL}$ concentration. After $72 \mathrm{~h}$, cell-viability inhibition increased dramatically compared with $24 \mathrm{~h}$ and $48 \mathrm{~h}$. Thus, the cell-viability inhibition had the least average at $72 \mathrm{~h}$, which means that AME extract shows its potent effect after $72 \mathrm{~h}$. Interestingly, we also noted that MDA-MB231 cells treated with concentrations of 400 and $600 \mu \mathrm{g} / \mathrm{mL}$ experienced a fall in cell count when the concentration increased, besides undergoing structural alterations caused due to loss of architecture of epithelium, echinoid spikes, and cellular rounding visible after $48 \mathrm{~h}$ of treatment.

To learn whether apoptosis is related to the anti-proliferative effect and observed morphological changes, further analysis for the apoptosis process was done, using apoptosis assays, as one possible mechanism exerted by AME anti-proliferative effect is required.

Recently, in agreement with what has been found in this study, several reports have been made regarding the in vitro anticancer activity of some microalgae species using different human and mouse cell lines.

Sanjeewa et al. [51] assessed the anti-cancer effect of hexane fractions of Nannochloropsis oculata using various cell lines (A-549, HEP-3B, HCT-116, SW-480, and HL-60). Cells were incubated with different concentrations of hexane fractions for $24 \mathrm{~h}$ and the viability of the cells were measured using colorimetric 3-(4,5-dimethylthiazol-2-yl)-2,5-diphenyltetrazolium bromide (MTT) assay. The authors performed a cytotoxicity study and observed that there was a substantial dose-dependent decrease in the viability of cancer cell lines. Microalgae may, therefore, represent an interesting source of biologically active moieties that can be considered as promising anti-cancer agents for clinical prospects.

\section{Conclusions}

The outcomes of this study suggested there was substantial variance in the in vitro antioxidant, antimicrobial, and anticancer potential of Nannochloropsis oculata. Further research on the phytochemical compounds in the extract to recognize unique and novel constituents and to assess which compound/s is responsible for all these pharmacological activities and to evaluate their effects on in vivo 
models to enhance the system antioxidant function by defending against different oxidative stress-induced diseases.

Author Contributions: Conceptualization, A.F.W. and J.R.P. and A.M.; Data curation, A.F.W. and Y.A.D.; Formal analysis, A.F.W., Y.A.D., M.S.E., D.A.A.F., A.F. and S.A.R.; Investigation, A.F.W. and Y.A.D.; Methodology, A.F.W. and J.R.P.; Project administration, A.F.W. and P.G.M.R.; Resources A.F.W., Y.A.D., M.S.E. and D.A.A.F.; Software, A.F.W. and S.A.R.; Supervision J.R.P., P.G.M.R. and A.F.W.; Writing-original draft, A.F.W., A.F. and Y.A.D.; Writing-review and editing, A.F.W., A.M., Y.A.D., M.S.E. and D.A.A.F. All authors have read and agreed to the published version of the manuscript.

Funding: This research was funded by RAKMHSU-REC-123-2018-F-P and RSP-2020/190.

Acknowledgments: The authors wish to thank RAK Medical and Health Sciences University, Ras Al Khaimah, United Arab Emirates, for their research support for the RAKMHSU-REC-123-2018-F-P research project. The authors would like to extend their sincere appreciation to the Researchers Supporting Project Number (RSP-2020/190), King Saud University, Riyadh, Saudi Arabia.

Conflicts of Interest: The authors declare that there is no conflict of interest.

\section{References}

1. Wang, H.; Khor, T.O.; Shu, L.; Su, Z.-Y.; Fuentes, F.; Lee, J.-H.; Kong, A.-N.T. Plants vs. Cancer: A Review on Natural Phytochemicals in Preventing and Treating Cancers and Their Druggability. Anti-Cancer Agents Med. Chem. 2012, 12, 1281-1305. [CrossRef] [PubMed]

2. Thomford, N.; Senthebane, D.; Rowe, A.; Munro, D.; Seele, P.; Maroyi, A.; Dzobo, K. Natural Products for Drug Discovery in the 21st Century: Innovations for Novel Drug Discovery. Int. J. Mol. Sci. 2018, $19,1578$. [CrossRef] [PubMed]

3. Montaser, R.; Luesch, H. Marine Natural Products: A New Wave of Drugs? Future Med. Chem. 2011, 3, 1475-1489. [CrossRef] [PubMed]

4. Omar, W.M. Perspectives on the Use of Algae as Biological Indicators for Monitoring and Protecting Aquatic Environments, with Special Reference to Malaysian Freshwater Ecosystems. Trop. Life Sci. Res. 2010, 21, 51-67. [PubMed]

5. Barkia, I.; Saari, N.; Manning, S.R. Microalgae for High-Value Products towards Human Health and Nutrition. Mar. Drugs 2019, 17, 304. [CrossRef]

6. Kent, M.; Welladsen, H.M.; Mangott, A.; Li, Y. Nutritional Evaluation of Australian Microalgae as Potential Human Health Supplements. PLoS ONE 2015, 10, e0118985. [CrossRef]

7. Petersen, L.-E.; Kellermann, M.Y.; Schupp, P.J. Secondary Metabolites of Marine Microbes: From Natural Products Chemistry to Chemical Ecology. In YOUMARES 9-The Oceans: Our Research, Our Future; Springer: Berlin/Heidelberg, Germany, 2019; Volume 1, pp. 159-180.

8. Nethravathy, M.U.; Jitendra, G.M.; Sandeep, N.M.; Ajam, Y.S. Recent Advances in Microalgal Bioactives for Food, Feed, and Healthcare Products: Commercial Potential, Market Space, and Sustainability. Compr. Rev. Food Sci. Food Saf. 2019, 18, 1882-1897.

9. Barbosa-Filho, J.M.; Alencar, A.A.; Nunes, X.P.; Tomaz, A.C.D.A.; Sena-Filho, J.G.; Athayde-Filho, P.F.; Silva, M.S.; Souza, M.F.V.D.; Da-Cunha, E.V.L. Sources of Alpha-, Beta-, Gamma-, Delta- and Epsilon-Carotenes: A Twentieth Century Review. Rev. Bras. Farmacogn. 2008, 18, 135-154. [CrossRef]

10. Matta, C.B.B.D.; Souza, É.T.D.; Queiroz, A.C.D.; Lira, D.P.D.; Araújo, M.V.D.; Cavalcante-Silva, L.H.A.; Miranda, G.E.C.D.; Araújo-Júnior, J.X.D.; Barbosa-Filho, J.M.; Santos, B.V.D.O.; et al. Antinociceptive and Anti-Inflammatory Activity from Algae of the Genus Caulerpa. Mar. Drugs 2011, 9, 307-318. [CrossRef]

11. Alves, C.; Silva, J.; Pinteus, S.; Gaspar, H.; Alpoim, M.C.; Botana, L.M.; Pedrosa, R. From Marine Origin to Therapeutics: The Antitumor Potential of Marine Algae-Derived Compounds. Front. Pharmacol. 2018, 9, 777. [CrossRef]

12. Azamjah, N.; Soltan-Zadeh, Y.; Zayeri, F. Global Trend of Breast Cancer Mortality Rate: A 25-Year Study. Asian Pac. J. Cancer Prev. 2019, 20, 2015-2020. [CrossRef] [PubMed]

13. Mehanna, J.; Haddad, F.G.; Eid, R.; Lambertini, M.; Kourie, H.R. Triple-Negative Breast Cancer: Current Perspective on the Evolving Therapeutic Landscape. Int. J. Women's Health 2019, 11, 431-437. [CrossRef] [PubMed] 
14. Varghese, E.; Samuel, S.; Abotaleb, M.; Cheema, S.; Mamtani, R.; Büsselberg, D. The "Yin and Yang" of Natural Compounds in Anticancer Therapy of Triple-Negative Breast Cancers. Cancers 2018, 10, 346. [CrossRef] [PubMed]

15. Calcabrini, C.; Catanzaro, E.; Bishayee, A.; Turrini, E.; Fimognari, C. Marine Sponge Natural Products with Anticancer Potential: An Updated Review. Mar. Drugs 2017, 15, 310. [CrossRef]

16. Wali, A.F.; Majid, S.; Rasool, S.; Shehada, S.B.; Abdulkareem, S.K.; Firdous, A.; Beigh, S.; Shakeel, S.; Mushtaq, S.; Akbar, I.; et al. Natural Products against Cancer: Review on Phytochemicals from Marine Sources in Preventing Cancer. Saudi Pharm. J. 2019, 27, 767-777. [CrossRef]

17. Ratovitski, E. Anticancer Natural Compounds as Epigenetic Modulators of Gene Expression. Curr. Genom. 2017, 18, 175-205. [CrossRef]

18. Andrade, K.M.; Lauritano, C.; Romano, G.; Ianora, A. Marine Microalgae with Anti-Cancer Properties. Mar. Drugs 2018, 16, 165. [CrossRef]

19. Borowitzka, M.A. Biology of Microalgae. In Microalgae in Health and Disease Prevention; Academic Press: Cambridge, MA, USA, 2018; pp. 23-72.

20. Matos, J.; Cardoso, C.; Bandarra, N.M.; Afonso, C. Microalgae as Healthy Ingredients for Functional Food: A Review. Food Funct. 2017, 8, 2672-2685. [CrossRef]

21. Sharifah, E.N.; Eguchi, M. The phytoplankton Nannochloropsis oculata enhances the ability of Roseobacter clade bacteria to inhibit the growth of fish pathogen Vibrio anguillarum. PLoS ONE 2011, 6, e26756. [CrossRef]

22. Aryal, S.; Baniya, M.K.; Danekhu, K.; Kunwar, P.; Gurung, R.; Koirala, N. Total Phenolic Content, Flavonoid Content and Antioxidant Potential of Wild Vegetables from Western Nepal. Plants 2019, 8, 96. [CrossRef]

23. Shi, P.; Du, W.; Wang, Y.; Teng, X.; Chen, X.; Ye, L. Total Phenolic, Flavonoid Content, and Antioxidant Activity of Bulbs, Leaves, and Flowers Made from Eleutherine Bulbosa (Mill.) Urb. Food Sci. Nutr. 2018, 7, 148-154. [CrossRef] [PubMed]

24. Siddhuraju, P.; Manian, S. The Antioxidant Activity and Free Radical-Scavenging Capacity of Dietary Phenolic Extracts from Horse Gram (Macrotyloma Uniflorum (Lam.) Verdc.) Seeds. Food Chem. 2007, 105, 950-958. [CrossRef]

25. Akbar, M.; Mubashir, H.M.; Adil, F.W.; Mudasir, A.M.; Nida, S.S. Antioxidant potential of methanolic root extract of Mentha arvensis L. From Kashmir region. J. Appl. Pharm. 2014, 4, 50-57.

26. Ramakrishna, J.; Wali, A.F.; Bakhit, F.E.M.; Elawad, A.O.; Ayaabdin, A. In Vitro Antioxidant Activity and Quantitative Elemental Analysis of Adansonia Digitata L. Fruit Using Inductively Coupled Plasma Optical Emission Spectroscopy. Ann. Phytomed. 2019, 8, 127-133. [CrossRef]

27. Lee, K.J.; Oh, Y.C.; Cho, W.K.; Ma, J.Y. Antioxidant and Anti-Inflammatory Activity Determination of One Hundred Kinds of Pure Chemical Compounds Using Offline and Online Screening HPLC Assay. Evid.-Based Complement. Altern. Med. 2015, 2015, 1-13. [CrossRef]

28. National Committee for Clinical Laboratory Standards (NCCLS). Introduces New Editions of Antimicrobial Susceptibility Testing Standards. Clin. Microbiol. Newsl. 1997, 19, 40. [CrossRef]

29. Khan, M.I.; Shin, J.H.; Kim, J.D. The Promising Future of Microalgae: Current Status, Challenges, and Optimization of a Sustainable and Renewable Industry for Biofuels, Feed, and Other Products. Microb. Cell Fact. 2018, 17, 36. [CrossRef]

30. Yan, S.; Asmah, R. Comparison of Total Phenolic Contents and Antioxidant Activities of Turmeric Leaf, Pandan Leaf and Torch Ginger Flower. Int. Food Res. J. 2010, 17, 417-423.

31. Panche, A.N.; Diwan, A.D.; Chandra, S.R. Flavonoids: An Overview. J. Nutr. Sci. 2016, 5, e47. [CrossRef]

32. Farasat, M.; Khavari-Nejad, R.-A.; Nabavi, S.M.B.; Namjooyan, F. Antioxidant Properties of Two Edible Green Seaweeds from Northern Coasts of the Persian Gulf. Jundishapur J. Nat. Pharm. Prod. 2013, 8, 47-52. [CrossRef]

33. Haoujar, I.; Cacciola, F.; Abrini, J.; Mangraviti, D.; Giuffrida, D.; Majdoub, Y.O.E.; Kounnoun, A.; Miceli, N.; Taviano, M.F.; Mondello, L.; et al. The Contribution of Carotenoids, Phenolic Compounds, and Flavonoids to the Antioxidative Properties of Marine Microalgae Isolated from Mediterranean Morocco. Molecules 2019, 24, 4037. [CrossRef] [PubMed]

34. Maadane, A.; Merghoub, N.; Ainane, T.; Arroussi, H.E.; Benhima, R.; Amzazi, S.; Bakri, Y.; Wahby, I. Antioxidant Activity of Some Moroccan Marine Microalgae: Pufa Profiles, Carotenoids and Phenolic Content. J. Biotechnol. 2015, 215, 13-19. [CrossRef] [PubMed] 
35. Ebrahimzadeh, M.A.; Khalili, M.; Dehpour, A.A. Antioxidant Activity of Ethyl Acetate and Methanolic Extracts of Two Marine Algae, Nannochloropsis Oculata and Gracilaria Gracilis-An in Vitro Assay. Braz. J. Pharm. 2018, 54, e17280. [CrossRef]

36. Horincar, V.B.; Parfene, P.; Bahrim, G. Evaluation of Bioactive Compounds in Extracts Obtained from Three Romanian Marine Algae Species. Rom. Biotechnol. Lett. 2011, 16, 71-78.

37. Zakaria, N.A.; Ibrahim, D.; Sulaiman, S.F.; Supardy, A. Assessment of Antioxidant Activity, Total Phenolic Content and In vitro Toxicity of Malaysian Red Seaweed, Acanthophora Spicifera. J. Chem. Pharm. 2011, 3, 182-191.

38. Li, X. 2-Phenyl-4,4,5,5-Tetramethylimidazoline-1-Oxyl 3-Oxide (PTIO•) Radical Scavenging: A New and Simple Antioxidant Assay in Vitro. J. Agric. Food Chem. 2017, 65, 6288-6297. [CrossRef]

39. Wang, G.; Li, X.C.; Zeng, H.P. Synthesis, Antioxidation Activity of (E)-9-p-Tolyl-3-[2-(8-hydroxy-quinol-2-yl) vinyl]-carbazole and (E)-9-(p-Anisyl)-3-[2-(8-hydroxy-quinol-2-yl) vinyl]-carbazole and Their Induction Proliferation of Mesenchymal Stem Cells. Acta Chim. Sin. 2009, 67, 974-982.

40. Gülçin, I.; Küfrevioğlu, Ö.; Oktay, M.; Büyükokuroǧlu, M.E. Antioxidant, Antimicrobial, Antiulcer and Analgesic Activities of Nettle (Urtica Dioica L). J. Ethnopharmacol. 2004, 90, 205-215. [CrossRef]

41. Millao, S.; Uquiche, E. Antioxidant Activity of Supercritical Extracts from Nannochloropsis Gaditana: Correlation with Its Content of Carotenoids and Tocopherols. Supercrit. Fluids 2016, 111, 143-150. [CrossRef]

42. Custódio, L.; Soares, F.; Pereira, H.; Rodrigues, M.J.; Barreira, L.; Rauter, A.P.; Alberício, F.; Varela, J. Botryococcus Braunii and Nannochloropsis Oculata Extracts Inhibit Cholinesterases and Protect Human Dopaminergic SH-SY5Y Cells from H2O2-Induced Cytotoxicity. J. Appl. Phycol. 2014, 27, 839-848. [CrossRef]

43. Kumar, S.S.; Saramma, A.V. In Vitro Antioxidant Activity and Total Phenolic Content of Nannochloropsis salina. Int. J. Pharmacogn. 2018, 10, 160-164.

44. Kokou, F.; Makridis, P.; Kentouri, M.; Divanach, P. Antibacterial Activity in Microalgae Cultures. Aquac. Res. 2011, 43, 1520-1527. [CrossRef]

45. Guimarães, A.C.; Meireles, L.M.; Lemos, M.F.; Guimarães, M.C.C.; Endringer, D.C.; Fronza, M.; Scherer, R. Antibacterial Activity of Terpenes and Terpenoids Present in Essential Oils. Molecules 2019, $24,2471$. [CrossRef]

46. Karimi, E.; Jaafar, H.Z.; Ghasemzadeh, A.; Ebrahimi, M. Fatty Acid Composition, Antioxidant and Antibacterial Properties of the Microwave Aqueous Extract of Three Varieties of Labisia Pumila Benth. Biol. Res. 2015, 48, 9. [CrossRef]

47. Bouarab-Chibane, L.; Forquet, V.; Lantéri, P.; Clément, Y.; Léonard-Akkari, L.; Oulahal, N.; Degraeve, P.; Bordes, C. Antibacterial Properties of Polyphenols: Characterization and QSAR (Quantitative Structure-Activity Relationship) Models. Front. Microbiol. 2019, 10, 829. [CrossRef]

48. Zanella, L.; Vianello, F. Microalgae of the Genus Nannochloropsis: Chemical Composition and Functional Implications for Human Nutrition. J. Funct. Foods 2020, 68, 103919. [CrossRef]

49. Fouad, Y.A.; Aanei, C. Revisiting the Hallmarks of Cancer. Am. J. Cancer Res. 2017, 7, 1016-1036.

50. Dyshlovoy, S.; Honecker, F. Marine Compounds and Cancer: Where Do We Stand? Mar. Drugs 2015, 13, 5657-5665. [CrossRef]

51. Sanjeewa, K.K.A.; Fernando, I.P.S.; Samarakoon, K.W.; Lakmal, H.H.C.; Kim, E.; Kwon, O.N.; Dilshara, M.G.; Lee, J.; Jeon, Y. Anti-inflammatory and anti-cancer activities of sterol rich fraction of cultured marine microalga Nannochloropsis oculata. Algae 2016, 31, 277-287. [CrossRef]

(C) 2020 by the authors. Licensee MDPI, Basel, Switzerland. This article is an open access article distributed under the terms and conditions of the Creative Commons Attribution (CC BY) license (http://creativecommons.org/licenses/by/4.0/). 